\title{
Effectiveness of Auditor General's Online Dashboard Disclosures: Qualitative Perspectives from Malaysian Members of Parliament
}

\author{
Ruhana Mohamad Zam ${ }^{1}$, Anuar Nawawi ${ }^{1}$ and Ahmad Saiful Azlin Puteh Salin ${ }^{2 *}$ \\ ${ }^{I}$ Faculty of Accountancy, Universiti Teknologi MARA, 40500 Shah Alam, Selangor, Malaysia \\ ${ }^{2}$ Faculty of Accountancy, Universiti Teknologi MARA, Perak Branch Tapah Campus, 35400 Perak, Malaysia
}

\begin{abstract}
The Malaysian Auditor General's Report is tabled in Parliament every year. This report covers issues from government ministries, departments, and agencies. Once the report is tabled, it is published to the public in hardcopy. Beyond a thick physical hardcopy, the emergence of information technology allows the public to browse, analyze, and review the report online via the Auditor General's Online Dashboard. However, the public and many other stakeholders, including Malaysian members of Parliament, are not aware of the existence of those facilities. Therefore, this research aims to gather information on the effectiveness of the Auditor General's Online Dashboard disclosure and whether such disclosures provide satisfactory information to users and particularly to members of Parliament. A qualitative survey of 30 members of Parliament through convenience sampling is used. This study found that lack of promotion contributed mostly to unawareness of the existence of the Auditor General's Online Dashboard disclosure.
\end{abstract}

Keywords: Auditor general, governance, integrity, public sector, transparency

ARTICLE INFO

Article history:

Received: 25 March 2020

Accepted: 04 November 2020

Published: 30 June 2021

DOI: https://doi.org/10.47836/pjssh.29.2.01

E-mail addresses:

suchee22@gmail.com (Ruhana Mohamad Zam)

anuar.nawawi@gmail.com (Anuar Nawawi)

ahmad577@uitm.edu.my (Ahmad Saiful Azlin Puteh Salin)

* Corresponding author

\section{INTRODUCTION}

Stakeholders have expressed their willingness and concern to evaluate the performance of public sector entities. In this regard, the literature has claimed that public sector entities must be held responsible for providing relevant performance-related information. Previous reports on international research on accountability perspectives have indicated that stakeholders in developed countries are more sophisticated and have a greater 
capacity and opportunity to exercise their rights in gathering information compared with stakeholders in less developed countries (Coombs \& Tayib, 1998).

In this context, the auditor general, as one of the more important federal government agencies, plays a major role in curbing corruption and acting as a watchdog over public funds expenditures. Amidst high mismanagement and misuse of public resources, as well as corruption, especially in developing countries, a major question asks how the Auditor General's Report ensures effective public financial management and accountability within government departments and improves service delivery.

For Malaysia, the fight against corruption has become a national priority. The Government Transformation Programme 2.0 is among the efforts taken by the Malaysian government to combat corruption via the reformation of public services. In the Government Transformation Programme 2.0, the overall theme of the Anti-Corruption National Key Result Area (NKRA) was broadened as compared with the Government Transformation Programme 1.0 to ensure greater efforts taken by enforcement agencies, including the auditor general, to stamp out corruption.

In addition, the government also established the National Governance, Integrity and Anti-Corruption Centre, which is responsible for formulating the best strategy and ensure all government policies and activities are done based on good governance and the highest level of integrity. Consequently, many initiatives have been implemented such as a more stringent code of conduct for Parliament members, asset declaration, disclosure of political donation, and founding of the Independent Police Complaints and Misconduct Commission.

In the fight against graft and corruption in the area of government transactions, particularly in government procurements and management of public funds, the Auditor General's Report has noted possible loopholes in the management of public funds and insufficient initiatives to combat this malpractices. In order to achieve the national objective of minimizing fraud and corruption in public fund management, the Government Transformation Programme 2.0 recommended transforming the auditor general's process to enhance its efficiencies and effectiveness in discharging its roles and responsibilities. These include fast-tracking access to the Auditor General's Performance Audit Report for Immediate Action, Action Committee on Auditor General's Report, Auditor General's Online Dashboard, and Putrajaya Inquisition.

The third initiative, which is the focus of this study, is the Auditor General's Online Dashboard disclosure, which was established to update issues arising from the Auditor General's Report. Its main objective is to promote transparency and induce pressure to expedite the resolution of issues raised in the report. The Auditor General's Online Dashboard disclosure was implemented under the administration of the National Audit Department of the Auditor General Office. The status of the issues, which appear on the Auditor General's Online 
Dashboard disclosure, is marked in three (3) different colors, i.e., Action in Progress to Resolve Issue (yellow), Issue Resolved (green), or No Action Pending to Resolve Issue (red). In addition, feedback from the related issues is also published on the web for public reference.

However, since its launch in August 2013, the feedback received is far from meeting expectations. An examination of the number of access or hits from the website shows low response received from the public, members of Parliament, and other stakeholders. Reasons for this may be due to a lack of awareness and less effort to make it known to the public. Despite the little feedback received, the National Audit Department has been contacted to answer and clarify several substantial questions relating to the Audit General's Report from Parliament.

In practice, the auditor general publishes three Auditor General Reports per year based on three separate performance audits of all public-sector entities. The Auditor General's Report is available online and may be accessed by a wide range of users. However, questions arise about how to fully utilize the Auditor General's Online Dashboard disclosures to promote transparency and how users and/or stakeholders are able to gain a summarization of the report.

Another concern is the notification and explanation to users and stakeholders about the roles and responsibilities of the auditor general, as most of the public response refers to enforcement-related action, which is contradictory to the power of duties of the auditor general as stipulated in the
Audit Act 1957. The Auditor General's Online Dashboard disclosures are intended to improve public perceptions of the actual auditor general's roles and responsibilities.

Based on this situation, this study will focus on details about the utilization, awareness, and expectations of Parliament toward the Auditor General's Online Dashboard. As elected members who represent the citizens, it is expected that the general public and members of Parliament particularly will pay attention to the information contained in the Auditor General's Report by conducting thorough analysis and offering professional judgment on the issues in the report that will benefit the country.

Thus, the purpose of the study is to analyze suggestions from Parliament for improvements to the Auditor General's Online Dashboard disclosures. Although the National Audit Department has provided convenient and accessible facilities for browsing the Auditor General's Report, stakeholders, the public, and members of Parliament are not aware that this facility exists. Therefore, this research aims to gather information on the perception of stakeholders about the implementation of the Auditor General's Online Dashboard disclosure and whether such disclosures provide satisfactory information.

This study offers several contributions. First, this study contributes to the innovation effort of the auditor general's activities and, hence, assists them in improving the guidelines of the Auditor General's Online Dashboard. Basically, the Auditor General's Report, which discusses issues 
from government ministries, departments, and agencies, is tabled in Parliament every year. Once the report is tabled, it will be published to the public in a hard copy. Despite reading a thick hardcopy version, the public and other stakeholders are now able to browse, analyze, and review the Auditor General's Report by clicking on the Auditor General's Online Dashboard, thanks to the advancement of the information and communication technologies. Unfortunately, not many people realize the benefits of this innovation. Findings from this study are, thus, essential to improve this initiative.

Second, this study provides valuable information that will support the National Audit Department to fulfill the Government Transformation Programme 2.0 's requirements. The auditors from the National Audit Department are required to form an opinion and report audit findings when conducting audit works, both for a performance audit and compliance audit of the government entities. Users of the Auditor General's Report are the public, members of Parliament, state legislative assembly members, and stakeholders. The Auditor General's Online Dashboard disclosure is part of the government's mechanism to channel all information to Parliament by offering members a clear view, with accurate and precise information, about the audit conducted by the National Audit Department.

Third, it is important to examine the effectiveness of the Auditor General's Online Dashboard to ensure this facility is fully utilized by the public and any interested parties as a mechanism to assess the performance of the government and its related agencies. Findings from this study will provide a significant confidence level to the country, as the Auditor General's Online Dashboard disclosures promote transparency by providing satisfactory information to the public. In addition, the information disclosed online is an important key performance indicator of the auditor general. Therefore, its planning and implementation should be properly handled to provide adequate user feedback and, hence, alleviate weaknesses of the government and its related agencies.

Fourth, findings from this research will increase government accountability because the Auditor General's Online Dashboard disclosures were launched with the objective of ensuring that the public and stakeholders are well informed of audit issues. Examination of its effectiveness will help the government to promote transparency by providing the current status of certain issues. Besides that, Auditor General's Online Dashboard disclosures are aimed at informing the public of selected matters of public interest, as reported in the auditor general's periodical reports. In Malaysia, for example, users or stakeholders of the Auditor General's Online Dashboard disclosure include government agencies, members of Parliament, state assembly members, private companies, taxpayers, and the public.

Finally, the findings of this study will add to the theory and body of literature on the important characteristics of government 
accountability in its effort to modernize public service delivery, particularly in the context of a developing country such as Malaysia. Prior studies concentrate more on government accountability in developed countries, e.g., the US, UK, and Europe.

This paper is organized as follows. Next is the literature review, followed by research issues. Section four discusses the research methodology, while section five includes findings and discussions of the study. Section six contains the conclusion. The last section reveals the study limitations and suggestions for future research.

\section{LITERATURE REVIEW}

\section{Public Sector Accountability}

Accountability concepts play an important role and contribute significantly to the image and positive perceptions of government organizations and related workforce. In the private sector, accountability is important to ensure shareholder wealth and other stakeholder interests are properly safeguarded via ethical decision-making by top management (Alias et al., 2019; Salin \& Ismail, 2015; Salin et al., 2020), transparent information disclosure (Jaafar et al., 2019; Salin et al., 2019), fraud prevention (Abidin et al., 2019), efficient corporate governance mechanisms (Nor et al., 2018; Shahar et al., 2020), and strong internal controls (Dangi et al., 2020; Nawawi \& Salin, 2018; Karim et al., 2018).

However, the concept and practice of accountability in the government and/or public sector is more profound and broader than in private organizations (McGregor,
1999; Parker \& Gould, 1999; Ryan et al., 2014; Samkin \& Schneider, 2010; Sinclair, 1995; Wynne, 2004) because government expenditures and operations are taxpayerfunded (Nawawi \& Salin, 2019; Shariman et al., 2017; Yusuf et al., 2020). For example, reports on financial and operational activities by government agencies should be more precise, informative, transparent, and accurate compared with their counterparts in the private sector (Monfardini, 2010; Nahar \& Yaacob, 2011; Nelson et al., 2003; Normanton, 1971; Turley et al., 2015). This is to ensure that government ministries, departments, and agencies are continuously efficient and effective in delivering services to the general public (Cooper \& Johnston, 2012; Shariman et al., 2018). Moreover, the regulation of government information has a significant effect on accountability (Zhiyuan, 2016), as government accountability is fundamental to democratic governance (Vlaicu \& Whalley, 2016). Gottlieb (2016), for example, documented that citizens are likely to sanction government officials that poorly perform and often vote for government officials and departments based on their performance.

Besides more voluntary disclosure, information that goes beyond rules and regulations is required to describe and satisfy the public and taxpayers on government activities and to improve life in the country. This consequently demonstrates government accountability (Boffa et al., 2016; Connolly \& Dhanani, 2006; Hyndman, 1990) and its impact on society (Torres \& Pina, 2003). In Malaysia, Tooley et al. (2010) found that 
stakeholders of local authorities in Malaysia showed strong interest in the performance of nontraditional information disclosed in financial statements, e.g., information related to the performance of outputs, outcomes, efficiency, and effectiveness. Because of this, the Auditor General's Online Dashboard was introduced as a determination by the government via its federal audit agencies to improve the operation and services of the government machinery. Our research here will contribute to the body of literature by sharing research findings of government accountability mechanisms implemented by audit departments, which is rarely found in the literature. Prior research on government accountability focused on local authorities and government link companies. Our research fills this gap.

\section{Auditor General's Online Dashboard Disclosures}

The implementation of the Government Transformation Programme 2.0 improved the process of disseminating information in the Auditor General's Report. The Auditor General's Online Dashboard disclosure is one of four initiatives established to achieve the Government Transformation Programme 2.0's goals. The main objective of the Auditor General's Online Dashboard is to inform the public via the Internet about issues concerning the Auditor General's Report in a concise and accurate manner. In addition, the dashboard promotes transparency, initiating pressure to expedite the resolution of issues raised in the Auditor General's Report and enhancing its public perceptions.
Users and stakeholders are able to browse the Auditor General's Online Dashboard disclosure through the official portal of the National Audit Department and click the link entitled "Auditor General's Dashboard Website." This homepage summarizes the number and status of the issue based on three (3) distinguished colors: Action In-Progress to Resolve Issue (yellow), Issue Resolved (green), or No Action Pending to Resolve Issue (red).

The public is also allowed to access a complete set of Auditor General's Reports by clicking on the icon of the Auditor General's Report on the official portal of the National Audit Department. However, matters on display are limited to specific areas of performance audit, in which the selection of issues is determined by the Cabinet Paper Guidelines. According to these guidelines, when selecting topics from the Auditor General's Report, the National Audit Department needs to consider eight categories: unreasonable price, improper payment, construction and supply specification, unreasonable delay, wastage, weakness in revenue management, vulnerability management, maintenance of public assets, and vulnerability management of the government.

\section{Preparation of the Auditor General's Online Dashboard}

The Audit Follow-Up Division, one of the units in the National Audit Department, is entrusted with the role of supplying information to the Auditor General's Online Dashboard disclosure. Activities in the 
preparation of the Auditor General's Online Dashboard disclosure are as follows:

Stage One: Recording of All Pertinent Matters and Feedback on Specific Areas of Performance Audits by Individual Audit Teams throughout the Country. Pertinent matters and feedback on specific areas of performance audits by individual audit teams throughout the country are recorded in a secured electronic database platform. The audit teams also propose a color-coded status of each matter and feedback, i.e., yellow, green, and red.

Stage Two: Selection of Pertinent Matters and Feedback on Specific Areas of Performance Audits. The Audit FollowUp Division extracts the pertinent matters on specific performance audit areas from the database. After the extraction is done, the Audit Follow-Up Division selects only certain pertinent matters on specific areas of performance audits based on the Cabinet Paper Guidelines. It forwards this data to the Information Technology Unit to be published on the website via the dashboard.

\section{Theoretical Framework}

This study used the legitimacy theory (Dowling \& Pfeffer, 1975) to explain the phenomenon of Auditor General's Online Dashboard disclosure and its effectiveness in delivering messages to related stakeholders. Based on this theory, an organization will actively seek ways to ensure its activities and existence are acceptable to stakeholders whose actions and claims have potential effects on an organization in question (Phillips, 2003). For example, a firm involved in urban development depends on local communities and local policymakers' support to ensure project success (Yang, 2014). Due to this, the National Audit Department must continuously improvise its services and operations to accommodate government policies and requirements. Thus, the Auditor General's Online Dashboard is introduced as an innovative mechanism to disclose the findings of its audit to stakeholders generally and to the public particularly. This disclosure is important to improve the performance of various government departments and their related agencies and, hence, safeguard public resources.

\section{METHOD}

This study employed a qualitative survey on 30 members of Parliament through convenience sampling. Due to the busy schedules, however, larger samples are not feasible for this study. There are 222 seats in the Malaysian Parliament. Currently, the Alliance of Hope (Pakatan Harapan) is the National Front, which is a rightwing coalition of political ruling parties in Malaysia. It involves the People's Justice Party (PKR), Democratic Action Party (DAP), National Trust Party (Amanah), and Malaysian United Indigenous Party (Bersatu). The other coalition is the National Front (Barisan Nasional), which represents the largest opposition members in Parliament. This coalition includes three parties, i.e., United Malays National 
Organisation (UMNO), Malaysian Chinese Association (MCA), and Malaysian Indian Congress (MIC). The respondents are the main group of stakeholders involved both directly and indirectly with the Auditor General's Online Dashboard.

A survey, which contains an open-ended question asking their opinions on suggested improvements to increase the effectiveness of the Auditor General's Online Dashboard disclosure, was distributed by hand to selected respondents. The questions were developed based on the literature. The initially proposed questions were examined and validated by experts in the relevant field of this research. This is to ensure the construct validity of the research. The questions were refined and amended based on expert advice. The qualitative data collected for this study were analyzed based on Malhotra (2010), which involved data reduction, data display, and conclusion. Data reduction is the stage in which all unnecessary and nonrelevant information is removed, leaving the utmost important information. This information is then mapped via a visual diagram to determine patterns and relationships. Finally, the meaning and significance of this pattern or relationship are analyzed and associated with the objectives of the study. The data collected were analyzed by using qualitative data analysis software. In addition to the open-ended questions, demographic questions on gender, age, education background, length of time as a member of Parliament, and political affiliation also were asked.

\section{FINDINGS AND DISCUSSION}

Based on 30 questionnaires distributed to the respondents, only seven $(23 \%)$ of the respondents replied to the questionnaires. Demographic profiles of the respondents are shown in Table 1 and Table 2.

It has been widely accepted that the Auditor General's Online Dashboard disclosure allows the National Audit Department to improve its performance in disseminating information to the public and other stakeholders. The results of the survey provided insight into the current state of the Auditor General's Online Dashboard disclosure and the perceptions from stakeholders, particularly from members of Parliament. Generally, members of

Table 1

Demographic profiles of respondents

\begin{tabular}{lcc}
\hline & $n$ & Percentage \\
\hline Gender & & \\
\hline Male & 0 & 100 \\
Female & & 0 \\
\hline Age & 2 & 28 \\
\hline Less than 30 years & 1 & 14 \\
30 to 40 years & 3 & 43 \\
41 to 50 years & 1 & 14 \\
More than 50 years & & \\
\hline Qualification & 1 & 14 \\
\hline Diploma & 3 & 72 \\
Degree & 3 & 14 \\
Professional & & \\
\hline Political experience & 2 & 28 \\
\hline Less than 5 years & 5 & 72 \\
\hline 5 years and more & & 58 \\
\hline Political affiliation & 4 & 43 \\
\hline National Front & 3 & \\
Alliance of Hope & & \\
\hline
\end{tabular}


Table 2

Individual profiles of respondents

\begin{tabular}{llllll}
\hline Respondents & Gender & Age & Qualification & Political experience & Political affiliation \\
\hline R1 & Male & 41 to 50 years & Professional & 5 years and more & National Front \\
R2 & Male & 41 to 50 years & Degree & Less than 5 years & Alliance of Hope \\
R3 & Male & 30 to 40 years & Degree & 5 years and more & Alliance of Hope \\
R4 & Male & Less than 30 years & Degree & Less than 5 years & National Front \\
R5 & Male & More than 50 & Diploma & 5 years and more & Alliance of Hope \\
& & years & & & \\
R6 & Male & 41 to 50 years & Degree & 5 years and more & National Front \\
R7 & Male & Less than 30 years & Degree & 5 years and more & National Front \\
\hline
\end{tabular}

Parliament perceive the potential benefits associated with the Auditor General's Online Dashboard.

\section{Promote the Auditor General's Online Dashboard}

In examining the effectiveness of the Auditor General's Online Dashboard, this study revealed that enormous promotion is essential for the Auditor General's Online Dashboard disclosure implementation. Five (R1, R2, R3, R4, R6) out of seven respondents recommended this action. The National Audit Department has seriously considered suggestions from members of Parliament, as they are the main users of the Auditor General Online Dashboard. The question here, then, is how will the promotion be done?

\section{R3 concurs:}

"The dashboard currently is not well promoted. It needs to be comprehensively publicized so it is known, used, and utilized by the public. If not, it is itself a wasteful project."
$\mathrm{R} 1$, on the other hand, gave a more specific suggestion:

"The National Audit Department should promote it through the media such as giving an exclusive interview about this dashboard. All media (mainstream and online) can also be invited to a special workshop. Indirectly, media will disseminate the info to the public."

Specifically, referring to members of Parliament, R2 recommended,

"To do promotion by asking the National Audit Department to brief the members of Parliament regarding the Auditor General's Online Dashboard disclosure."

Based on these findings, there are many possible ways to promote the Auditor General's Online Dashboard disclosure. These issues may be addressed in a phaseby-phase manner. The National Audit Department planned that, in the initial phase, promotion would be targeted to members of Parliament, as they are the key persons using 
the Auditor General's Online Dashboard. Further, Parliament may debate the issues raised from this dashboard. Therefore, 222 Parliament members will be invited to attend the workshop, briefing, and seminar on the Auditor General's Online Dashboard disclosure, as organized by the National Audit Department.

\section{Better Coordination with Other Government Agencies on Enforcement Matters}

This study found that the Auditor General's Online Dashboard disclosure should be inter-relation with other enforcement government agencies such as the Malaysian Anti-Corruption Commission, Royal Police of Malaysia, and Attorney General of Malaysia. This is emphasized by the fact that respondents want the required action taken as a result of the report, especially on audit findings that reveal major weaknesses in government transactions, which is a significant waste of taxpayer money.

R5 advocates,

"Invite NGOs like Transparency International-Malaysia (TI-M) to monitor this Auditor General's Dashboard. Transparency International can set up its own public monitoring system, which can complement the Auditor General's Dashboard, lending strength and support to the Auditor General's Report, so that Parliament, the Public Account Committee, and public officials, will know they are being watched, too."
This is supported by R6:

"To inter-relation with other government machineries such as Ministry of Finance, Transportation, Health, Human Resources, and other related agencies."

The findings suggest the important role and responsibility played by the National Audit Department to carry out audits in a professional and independent manner and to produce a balanced report to Parliament and state legislature toward enhancing good governance in the public sector. In this context, cooperation is essential as a bridge for sharing responsibilities in enhancing good governance in the public sector in Malaysia. In addition, the objectives of the government transformation program are to reduce bribery, misappropriation, and leakage in the public sector. Thus, via cooperation with those enforcement agencies, it allows efficient investigation on the issues addressed in the Auditor General's Report. The collaboration chain is also necessary to improve the government system as well as public perceptions.

\section{Better Interaction with the Public or the Stakeholders}

The Auditor General's Online Dashboard disclosure should be user-friendly so that it is able to facilitate interaction between the public and the National Audit Department. This is important, as stakeholders, especially the public, can also participate and provide feedback on the findings in the dashboard. This indirectly will increase the support 
of the public toward government efforts to combat leakages in the public fund expenditures and prevent unethical practices.

This is suggested by R2:

"To have a direct link to the responsible officer so that further action can be taken as a result of complaint or info from a whistleblower on the scandal"

R5 supports this suggestion:

"Should add a 'recommendation button' from the auditor general or others to give their opinion on the problem or give solutions."

R6 commends the interaction between the public and government:

"Should be user-friendly and allow the public to raise comments or interactions with the National Audit Department."

Based on these responses, there should be mechanisms or modules to improve the efficiency of the Auditor General's Online Dashboard. The interactive system will provide an opportunity for the public to give comments, get a clear explanation on the issues raised, and demonstrate transparent actions taken to resolve issues. By taking all these considerations into account, the interactive module will attract people to know what is really transparently happening in the government. This will enable stakeholders to be more satisfied with government services.

\section{Improve Monitoring of the Issues}

The Auditor General's Online Dashboard disclosure must be monitored to ensure that appropriate action is taken by an auditee in regard to the published issue. If the Auditor General's Online Dashboard disclosure provides prompt updates on the status of feedback, the public or the stakeholders are will know the actual status of the issues instantly.

This was emphasized by R5:

"The Auditor General's Dashboard
should have information about
any action that has been taken
against those who had failed to
fulfill their commitments. A list
of blacklisted companies can be
added to this Auditor General's
Dashboard website."

Collaboration between the auditee and the National Audit Department is necessary in order to take specific action to deal with the issues and to deliver the feedback quickly to the person concerned. Although the process of monitoring the issues appears simple, it actually involves several processes and agencies or auditees. The public should be given the awareness that certain issues will take long periods to solve. This is because it may involve prosecution or require a charge. Thus, feedback status will remain the same until it is completely resolved. The chronology and related records due to prosecution or arguments over the issues will also remain confidential. Only general information will be provided and disclosed. 


\section{Upgrade the Future Version of the Auditor General's Online Dashboard}

The study indicates a need for the National Audit Department to take more serious consideration of the system limitations as well as the server capability of the Auditor General's Online Dashboard disclosure.

For example, R7 opined,

"The layout and the design of the Auditor General's Online Dashboard disclosure should be enhanced and improved in order to attract the public to browse the system more frequently."

R2 shared his experience:

"I tried to browse the online dashboard, which was difficult to find on your (National Audit Department) website. It should have a visible tab for easy recognition."

R5 concurs with a similar tone:

\section{"The Auditor General's Dashboard should be an easy access for the people and rakyat (public) to monitor the weaknesses in management, efforts on enhancing accountability and integrity toward good governance."}

Since its implementation, the Auditor General's Online Dashboard disclosure has undergone several changes in the listing of programs to ensure it meets its objectives, even though the cost of development was tight. Due to the emerging issue of public awareness of the content of the
Auditor General's Report, the role of the Auditor General's Online Dashboard disclosure has become crucial. For this reason, the Ministry of Finance approved about RM1.8 million for system upgrades and a dedicated server to accommodate modules, as requested by the public and Parliament. Under this consideration, several brainstorming sessions with various parties should be organized to explore and discuss their concerns and ways to fulfill their requirements.

\section{CONCLUSIONS}

An audit is an independent activity that produces transparency reports for clients, stakeholders, and the public. In this regard, evaluation of audit reports is essential, as it provides a basis for measuring transparency, integrity, and reliability. This research is conducted as part of a contribution to public-sector auditing for the improvement of the Auditor's General Reports in terms of isolating significant issues, disseminating information, and develop a good rapport between government agencies and the public.

The Auditor General's Online Dashboard disclosure was launched in August 2013. However, fewer responses were received from the public, members of Parliament, and stakeholders in regard to this system. For this reason, this study is intended to examine their awareness and perceptions on the implementation of the Auditor General's Online Dashboard. In view of the fact that the Auditor General's Online Dashboard disclosure is a new system introduced 
by the National Audit Department, this study aims to contribute to the innovation and improvement of the auditor general's activities and establish comprehensive guidelines for the Auditor General's Online Dashboard disclosure system.

The qualitative survey, which has been distributed to Members of Parliament, suggests that an enormous promotion of the Auditor General's Online Dashboard, the appointment of the liaison officer, inter-relation communication between government agencies, effective monitoring of the issues, and using the latest technology to upgrade to the current version to increase the effectiveness of the dashboard.

\section{LIMITATIONS OF THE STUDY AND SUGGESTIONS FOR FUTURE RESEARCH}

The scope of this study is limited to a small sample. General views and opinions of the Auditor General's Online Dashboard disclosure implementation were only gathered through feedback via members of Parliament. In addition, some information may not be disclosed due to the personal requirements of Parliament members. In addition, some facts cannot be disclosed due to confidentiality.

Stakeholders of the Auditor General's Report are varied; however, primary users formed the Auditor General's Online Dashboard disclosures, although this study's analysis was limited by the number of Parliament members who responded. Thus, the sample size is a major limitation of this study. Future research should be conducted by taking a broader view of the stakeholders.
Future research should be focused on stakeholder requirements and the issues raised by every group of stakeholders, e.g., the public. Another data collection method, e.g., mass-market survey, can be utilized to gather more participants. More questions may also be asked and other types of analysis methods involving statistical modelling can be employed to generate more robust, reliable, and validated findings.

\section{ACKNOWLEDGMENTS}

Authors would like to thank the anonymous participants for their cooperation and time in providing the researcher all the needed information.

\section{REFERENCES}

Abidin, M. A. Z., Nawawi, A., \& Salin, A. S. A. P. (2019). Customer data security and theft: A Malaysian organization's experience. Information and Computer Security, 27(1), 81100. https://doi.org/10.1108/ICS-04-2018-0043

Alias, N. F., Nawawi, A., \& Salin, A. S. A. P. (2019). Internal auditor's compliance to code of ethics: Empirical findings from Malaysian governmentlinked companies. Journal of Financial Crime, 26(1), 179-194. https://doi.org/10.1108/JFC-072017-0066

Boffa, F., Piolatto, A., \& Ponzetto, G. A. (2016). Political centralization and government accountability. The Quarterly Journal of Economics, 131(1), 381-422. https://doi. org/10.1093/qje/qjv035

Connolly, C., \& Dhanani, A.V. (2006). Accounting narratives: The reporting practices of British charities. In B. Helmig, N. Hyndman, M. Jergers, \& I. Lapsley (Eds.), On the challenges of managing the third sector (pp. 39-62). Nomos. 
Coombs, H. M., \& Tayib, M. (1998, August 4-6). Developing a disclosure index for local authority published accounts - A comparative study of local authority published financial reports between the $U K$ and Malaysia [Paper presentation]. Asian Pacific Interdisciplinary Research in Accounting Conference, Osaka, Japan.

Cooper, C., \& Johnston, J. (2012). Vulgate accountability: Insights from the field of football. Accounting, Auditing \& Accountability Journal, 25(4), 602-634. https://doi. org/10.1108/09513571211225060

Dangi, M. R. M., Nawawi, A., \& Salin, A. S. A. P. (2020). Application of COSO framework in whistleblowing activities: A case study of public higher learning institution. International Journal of Law and Management, 62(2), 193-211. https:// doi.org/10.1108/IJLMA-06-2017-0145

Dowling, J., \& Pfeffer, J. (1975). Organizational legitimacy: Social values and organizational behavior. The Pacific Sociological Review, 18(1), 122-136. https://doi.org/10.2307/1388226

Gottlieb, J. (2016). Greater expectations: A field experiment to improve accountability in Mali. American Journal of Political Science, 60(1), 143-157. https://doi.org/10.1111/ajps.12186

Hyndman, N. (1990). Charity accounting: An empirical study of the information needs of contributors to UK fund raising charities. Financial Accountability \& Management, 6(4), 295-307. https://doi.org/10.1111/j.1468-0408.1990. tb00335.x

Jaafar, M. Y., Nawawi, A., \& Salin, A. S. A. P. (2019). Factors influencing directors' remuneration disclosure in Malaysian PLCs. Pertanika Journal of Social Science and Humanities, 27(2), 10491071.

Karim, N. A., Nawawi, A., \& Salin, A. S. A. P. (2018). Inventory management effectiveness of a manufacturing company-Malaysian evidence. International Journal of Law and Management,
60(5), 1163-1178. https://doi.org/10.1108/ IJLMA-04-2017-0094

Malhotra, N. K. (2010). Marketing research: An applied orientation. Pearson Education Limited.

McGregor, W. (1999). The pivotal role of accounting concepts in the development of public sector accounting standards. Australian Accounting Review, 9(1), 3-8. https://doi. $\operatorname{org} / 10.1111 / \mathrm{j} .1835-2561.1999 . t b 00093 . x$

Monfardini, P. (2010). Accountability in the new public sector: A comparative case study. International Journal of Public Sector Management, 23(7), 632-646. https://doi. org/10.1108/09513551011078897

Nahar, H. S., \& Yaacob, H. (2011). Accountability in the sacred context: The case of management, accounting and reporting of a Malaysian cash awqaf institution. Journal of Islamic Accounting and Business Research, 2(2), 87-113. https://doi. org/10.1108/17590811111170520

Nawawi, A., \& Salin, A. S. A. P. (2018). Slow moving stock problem: Empirical evidence from Malaysia. International Journal of Law and Management, 60(5), 1148-1162. https://doi. org/10.1108/IJLMA-06-2017-0142

Nawawi, A., \& Salin, A. S. A. P. (2019). The effectiveness of public school fund distribution: A case study of poor student trust fund. Pertanika Journal of Social Science and Humanities, 27(2), 877-897.

Nelson, M., Banks, W., \& Fisher, J. (2003). Improved accountability disclosures by Canadian universities. Canadian Accounting Perspectives, 2(1), 77-107. https://doi.org/10.1506/1H5WR5DC-U15T-KJPH

Nor, N. H. M., Nawawi, A., \& Salin, A. S. A. P. (2018). The impact of audit committee independence and auditor choice on firms' investment level. Pertanika Journal of Social Science and Humanities, 26(3), 1433-1454. 
Normanton, E. L. (1971). Public accountability and audit: A reconnaissance. In B. R. Smith \& D. C. Hague (Eds.), The dilemma of accountability in modern government: Independence versus control (pp. 311-345). MacMillan.

Parker, L., \& Gould, G. (1999). Changing public sector accountability: Critiquing new directions. Accounting Forum, 23(2), 109-135.

Phillips, R. (2003). Stakeholder legitimacy. Business Ethics Quarterly, 13(1), 25-41.

Ryan, C., Mack, J., Tooley, S., \& Irvine, H. (2014). Do not-for-profits need their own conceptual framework? Financial Accountability \& Management, 30(4), 383-402. https://doi. org/10.1111/faam.12044

Salin, A. S. A., \& Ismail, Z. (2015). Ethics practices of Malaysian public listed companies - Empirical evidence. Proceedings of the 10th Annual London Business Research Conference. World Business Institute.

Salin, A. S. A. P., Ismail, Z., Smith, M., \& Nawawi, A. (2019). Board ethical commitment and corporate performance: Malaysian evidence. Journal of Financial Crime, 26(4), 1146-1164. https://doi. org/10.1108/JFC-10-2017-0099

Salin, A. S. A. P., Manan, S. K. A., \& Kamaluddin, N. (2020). Ethical framework for directors Learning from the Prophet. International Journal of Law and Management, 62(2), 171-191. https:// doi.org/10.1108/IJLMA-04-2018-0075

Samkin, G., \& Schneider, A. (2010). Accountability, narrative reporting and legitimation: The case of a New Zealand public benefit entity. Accounting, Auditing \& Accountability Journal, 23(2), 256-289. https://doi. org/10.1108/09513571011023219

Shahar, N. A., Nawawi, A., \& Salin, A. S. A. P. (2020). Shari'a corporate governance disclosure of Malaysian IFIs. Journal of Islamic Accounting and Business Research, 11(4), 845-868. https:// doi.org/10.1108/JIABR-05-2016-0057
Shariman, J., Nawawi, A., \& Salin, A. S. A. P. (2017). Public sector accountability - Evidence from the auditor general's reports. Management \& Accounting Review, 16(2), 231-257. http:// dx.doi.org/10.24191/mar.v16i2.548

Shariman, J., Nawawi, A., \& Salin, A. S. A. P. (2018). Issues and concerns on statutory bodies and federal government - Evidence from Malaysian Auditor General's report. International Journal of Public Sector Performance Management, 4(2), 251-265. https://doi.org/10.1504/ IJPSPM.2018.090757

Sinclair, A. (1995). The chameleon of accountability: Forms and discourses. Accounting, Organizations and Society, 20(2), 219-237. https://doi. org/10.1016/0361-3682(93)E0003-Y

Tooley, S., Hooks, J., \& Basnan, N. (2010). Performance reporting by Malaysian local authorities: Identifying stakeholder needs. Financial Accountability \& Management, 26(2), 103-133. https://doi.org/10.1111/j.14680408.2009.00478.x

Torres, L., \& Pina, V. (2003). Accounting for accountability and management in NPOs - A comparative study of four countries: Canada, the United Kingdom, the USA and Spain. Financial Accountability \& Management, 19(3), 265-285. https://doi.org/10.1111/1468-0408.00174

Turley, G., Robbins, G., \& McNena, S. (2015). A framework to measure the financial performance of local governments. Local Government Studies, 41(3), 401-420. https://doi.org/10.1080/030039 30.2014 .991865

Vlaicu, R., \& Whalley, A. (2016). Hierarchical accountability in government. Journal of Public Economics, 134, 85-99. https://doi.org/10.1016/j. jpubeco.2015.12.011

Wynne, A. (2004). Public sector accounting: Democratic accountability or market rules? Public Money \& Management, 24(1), 5-7. https:// doi.org/10.1111/j.1467-9302.2004.00385.x 
Yang, R. J. (2014). An investigation of stakeholder analysis in urban development projects: Empirical or rationalistic perspectives. International Journal of Project Management, 32(5), 838-849. https://doi.org/10.1016/j.ijproman.2013.10.011

Yusuf, Z., Nawawi, A., \& Salin, A. S. A. P. (2020). The effectiveness of payroll system in the public sector to prevent fraud. Journal of Financial
Crime, Ahead-of-print. https://doi.org/10.1108/ JFC-08-2017-0075

Zhiyuan, X. U. E. (2016). Study on the administrative accountability system: From the perspective of the government information publicity. Canadian Social Science, 12(3), 73-78. http://dx.doi. org/10.3968/\%25x 